the above months, and you have the results; so evidently they are not common in the part we were in. The curious thing is that, although we searched for weeks, we never found another specimen. The natives told me they found them at the roots of grass, under stones, and at the damp roots of clumps of bamboo."

Until the Ceram species was described it was quite uncertain whether the Papuan species would, when discovered, be found to belong to the Australian type or to the New Britain type, or to neither. Messrs. Muir and Kershaw's discovery settled that point. As a result of their work we know that Peripatus ceramensis belongs to the group Melano-Peripatus. It was therefore to be expected that the Papuan species would belong to the same type, as indeed it does. I propose to name the species papuensis, with the following characters:-

Peripatus papuensis, n.sp. Colour very similar to that of Capo-Peripatus, the principal pigments being a greenishblue and an orange. Number of legs is variable, from twenty-three to twenty-nine pairs. Legs with three spinous pads. Nephridial openings of legs four and five on the proximal pad. Feet with three distal papillæ, of which one is anterior, one posterior, and one dorsal. Genital opening subterminal behind the legs of the last pair. Ovary small, with small ova (size not determined). Oviduct with a receptaculum seminis. Uterine embryos of very different ages in the same uterus. Spirit specimens which have been killed extended reach a length of $3 \frac{1}{4}$ inches.

From this it seens fairly clear that we are dealing with a Melano-Peripatus. As the specimens are admirably preserved I hope soon to be able to work out the other characters. A. SEDGwick.

Imperial College of Science and Technology, May I3.

\section{The Bibliography of the Biology of the European Seas.}

MaY I through the columns of NaTURE direct attention to the fact that the Bureau of British Marine Biology, which for some time past has been engaged in the preparation of an extensive MS. bibliography of the fauna and flora of the European seas, is now making the experiment of printing and circulating, in the form of a periodical, the records which are thus being brought together?

The number of scientific journals has increased so enormously of late, and the output of biological work has now become so vast, that there would seem to be a very real need of some means by which the student may keep more fully in touch with the published work of his colleagues than is possible with the aid of the existing bibliographies alone; it has already become quite impossible for the specialist to himself search through all the various journals, \&c., as they appear (even should he be fortunate enough to have access to adequate libraries), and, at the same time, to accomplish any research work of his own.

The bibliography of European marine biology now in progress (the first part was published on April 2) in the "Contributions from the Bureau of British Marine Biology" aims at providing a full title-entry and summary of the contents of every publication as it appears which is in any way concerned with the biology of the European seas (including the North Atlantic, Arctic, and Mediterranean). These summaries will, in general, appear within a few weeks of the publication of the works to which reference is made, while entries in the existing annual bibliographies are, of course, necessarily at least one or two years behindhand. The analysis of works indexed by the Bureau is also carried very much further than is attempted in any existing bibliography; for instance, a separate entry is made for practically every mention of a species in the work analysed. In addition to the bibliography and analysis of current work, the MS. records of the Bureau also include extensive annotated lists of the marine fauna and flora, alphabetical reference lists of specific and subspecific names and synonyms, particulars of type-localities, trpe-specimens, \&c.; it is likewise intended to publish these records in the "Contributions." It may also be mentioned that all entries are being printed in such a form as will admit of their use as a card catalogue.

There is, of course, no desire to make a profit by the publication of these records, but, on the other hand, the
Bureau cannot afford to incur any considerable financial loss by the undertaking, and the publication of the bibliography will therefore not be proceeded with for any length of time unless there is by an early date distinct evidence that sufficient support will be forthcoming to meet the cost of printing. For this reason I would urge all who may be willing to assist the undertaking to notify as soon as possible their intention of subscribing. The bibliography will, I am sure, prove most useful to those interested in any department of marine research if only publication can be continued for a sufficient period to enable the "Contributions" to become established. Full particulars, forms for subscription, \&c., will be forwarded upon application to the undersigned.

6 Provost Road, Haverstock Hill, London, N.W., May II.

\section{An Improved Weight Dilatometer.}

THE ordinary form of weight dilatometer is troublesome to dry and fill, and the filling takes much time. Air bubbles are removed with difficulty, and after cooling to a low temperature there is a risk of loss of mercury while weighing the dilatometer unless special precautions are taken.

To obviate these disadvantages the form of dilatometer here illustrated has been devised. The neck of the dilatometer is short and straight, and is enclosed in a cylindrical cup projecting a few centimetres above the neck, and sealed on to the body of the dilatometer.

To dry the bulb, the cup is fitted with a cork and a piece of tubing, and connected to the water-pump. By gently heating the bulb and exhausting, moisture is removed. In the second form (Fig. 2) air is drawn through the bulb by removing the clip and pad from the side tube.

To fill the simpler form, Fig. I, dry mercury is poured into the cup; by gently tapping, the mercury falls into the bulb. The operation is repeated until the bulb is filled. To remove air from the neck the dilatometer is warmed, and when the mercury oozes out the cup is re-filled, and the dilatometer placed in ice water above the level of the

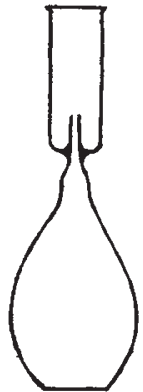

Fig. I.

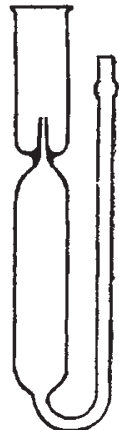

FIs. 2. neck. After cooling, the excess of mercury is poured out of the cup. The dilatometer is dried and weighed, any mercury expelled by expansion being collected in the cup. After heating to a higher temperature, the expelled mercury is poured out, and the dilatometer weighed after cooling. In the form shown in Fig. 2 the filling is more rapid, as air is expelled through the side tube; when this is filled with mercury the clip is fixed, and the tube closed by a screw pad. A. V. C. Fenby

The Wyggeston Boys' School, Leicester, May II.

\section{THE INTERNATIONAL ASSOCIATION OF ACADEMIES.}

Fourth Meeting, May 9-i4.

$\mathrm{T} T$ is now ten years since the association was inaugurated in a preliminary meeting held at Wiesbaden, and since then regular triennial assemblies have taken place in Paris, London, Vienna, and finally in Rome, where the fourth meeting, conducted under the presidency of Prof. P. Blaserna, of the Accademia dei Lincei, has just come to a close. The representatives of the Royal Society were Sir Archibald Geikie, Sir Joseph Larmor, Prof. Schäfer, ColoneI Prain, Prof. Turner, and Dr. Arthur Schuster. In judging of the past activity and the prospects of the association, it must be borne in mind that, having no funds at its disposal, its influence must be mainly 
a moral one. It is intended to coordinate international enterprises, to initiate and encourage undertakings, and to act as an advisory body where advice is asked for, either by Governments or by the many special international organisations which have recently sprung up. The list of resolutions passed at each meeting may appear meagre to those who do not realise that they represent only the crystallised results of the discussions which have come to an issue, and that it often takes a considerable time before questions can be presented in a sufficiently definite form to admit of treatment by an international committee which can only meet at rare intervals; but those who have watched the proceedings of the association do not doubt that it has justified its existence, and that there is an important future before it.

That part of the association's work which prevents the overlapping of international enterprises has been illustrated in Rome by the manner in which the proposal of the Swedish Academy to take international action towards the prevention of the diseases of cultivated plants was dealt with. Everyone agreed that the subject was a most important one, and feil within the province of the association, but there is in Rome an International Agricultural Institute, which might be expected to include remedial measures agrainst the diseases of plants within its range of activity. Apparently, however, there are difficulties which hitherto have prevented the Agricultural Institute from attacking the problem; these are partly financial, but partly also due to the terms of the convention under which the institute was founded. After a full discussion, the representative of the Swedish Academy accepted the following resolution, which was proposed by Colonel Prain, one of the representatives of the Royal Society :-

"The International Association of Academies of Science, while in entire sympathy with the proposal that further international cooperation in the study of plant diseases is necessary, considers that the question of deciding what ought to be done in the direction of combating these diseases might appropriately be entrusted to the International Agricultural Institute.

"In the event of its being found that the terms of the convention of 1905 , under which it was established, prevent the International Institute from extending its activities so far as is desired in the interests of science and agriculture, this association recommends that the constituent academies bring to the notice of their respective Governments the desirability of conferring adequate powers upon the International Agricultural Institute."

A further question in which the association endeavoured to prevent a possible overlapping of enterprises arose out of the proposal to give the support of the association to an international committee formed to prepare tables of "physico-chemical" constants. Here a consultation with the International Scientific Catalogue Committee seemed advisable, and the following resolution was adopted :-

"The International Association of Academies gives its patronage to the International Committee of Physico-chemical Tables, and expresses the wish that this committee put itself into communication with the International Committee of the Catalogue of Scientific Literature."

The coordination of international scientific work which results from the extension of the patronage of the International Association of Academies to different independent enterprises is an effective method which deserves to be further extended. The International Union for the Study of Solar Phenomena has set a cood example in this respect by asking the Association of Academies to nominate one of the three members of its executive committee. Prof. Riccò, of
Catania, was nominated two years ago as the member representing the Accademia dei Lincei when that body became the leading academy, and he will hold office until the end of the year, when a new member will be nominated by the academy which will next act as host to the International Association.

The scientific questions which are dealt with by the association are frequently handed over to autonomous committees which regulate their own proceedings and act very much like independent international bodies. All that appears at the meetings is a short report summarising the activity of the committee. One of these committees deals with the investigation of the functions of the brain, and works under the chairmanship of Prof. Waldeyer, of Berlin. The work of a number of institutes specially endowed in different countries for the study of this question is thus coordinated, and a more rapid progress is secured.

A very useful piece of work has been undertaken at the instigation of the Royal Society, with the object of introducing order into the chaos which reigns at present in the nomenclature of prominent features on the surface of the moon. The advice of all astronomers interested in the subject has been obtained, and a committee has been formed, under the presidency, first of M. Loewy, and since his death of Prof. Turner. Maps of the moon are being drawn by Mr. Wesley from maps supplied by the Paris observatories, and the details of the nomenclature, according to a definite scheme agreed upon, will then be prepared by Messrs. Saunders and Franz.

Questions which are of importance in the general theory of terrestrial magnetism have been under the consideration of a special committee almost since the foundation of the association. The general magnetic survey of the ocean basins which is being carried out by the Carnegie Institution of Washington is expected to prove of fundamental importance in this respect, and the work of the committee is dormant at present until that survey is more generally advanced.

The association has further interested itself in the publication of the collected works of Leibnitz, which is being promoted jointly by the Academies of Paris and Berlin, and in that of Euler's works, which has been undertaken by the Société helvétique des Sciences naturelles. The association has more especially approved at its recent meeting the decision to publish all memoirs in their original language. It may seen strange that such approval should be necessary, but it was called for by attempts that had been made to persuade the Swiss society to translate the Latin writings into a modern language.

A few words should perhaps be said on the literary side of the work of the association. The subjects dealt with included the preparation of an edition of the "Mahâbhârata," and of an "Encyclopædia of Islam," of Greek documents, and of a "Corpus Medicorum Antiquorum "; further, the very difficult question of an international exchange-by way of loan-of manuscripts belonging to public libraries.

That a young association should still have to devote a considerable part of its time to matters of organisation is not surprising, and there is one question which is likely to occupy its attention very seriously before a definite conclusion is reached. At present the association has no legal status, not being subject to the laws of any country. It cannot, therefore, accept any legacies, and it is rumoured that it has lost in consequence a very considerable sum of money. The simplest manner to overcome the difficulty would be to establish a domicile in some country, such as one of the smaller States of Europe. It is claimed by some that other advantages would accrue to the association if it had a definite home, and its business matters could no doubt be carried on in a more satis- 
factory manner; but at present there is still too wide a divergence of opinion to render a definite proposal generally acceptable. In order to evade the difficulty at present preventing the association from having funds of its own, the committee of the association, at a meeting held last year, at which nearly all the academies were represented, passed a unanimous resolution recommending that the different academies should declare themselves ready to accept legacies or gifts to be held in trust by them for the purposes of the association. When this resolution came up for discussion at the present meeting, objections were raised by several delegates, and the matter had to be referred to the several academies for an authoritative expression of opinion. Doubts were expressed in several quarters whether it would be advisable for the association to be in possession of funds, and at any rate one delegate thought that it would be more powerful if satisfied with its present "moral" force. 'Time, further reflection, and the force of circumstances will no doubt lead to a generally acceptable solution.

By the admission of the Société helvétique des Sciences naturalles, which was decided upon almost unanimously, the association has established the important, and, I believe, wise, principle that it attaches greater importance to the representation of countries in which important work is being done and of societies which take a leading part in such work than to the more or less exclusive tests of membership which a society may adopt. The Swiss society is not an academy in the old and perhaps proper sense. It may be the poorer for having no mediæval traditions, but it is the richer for not having adopted, without such traditions, a mediæval organisation.

Our association now consists of twenty-one societies, and fears have been expressed that our work would become more difficult if the number were to be increased substantially. These fears are not, perhaps, groundless, if the addition of a new society does not mean the inclusion of new interests and of independent directions of activity. Now, if we look at the proper balance of representation of such independent scientific activity, it seems altogether anomalous that the British Empire should only be represented by the Royal Society and the British Acadeny. The nonrepresentation of India more especially denotes a gap which should be filled without delay. Both on the literary and on the scientific side our work has dealt with matters in which India is directly concerned. The publication of the "Mahâbhârata," more especially, cannot be carried out without substantial help from India, and at the present meeting in Rome it was announced that several of the Indian native rulers have subscribed to the undertaking. In the Asiatic Society of Bengal, India possesses a society of full academic rank, and without it the International Association of Academies is not complete. Some formal changes in its organisation, the dropping of the word "Bengal" from its title (I understand that its inclusion was purely accidental and not originally intended), and an increased activity on the scientific side may be desirable, but even with its present organisation there is no reasonable doubt that a proposal coming from the Royal Society to add the Asiatic Society to the list of academies forming the union would be generally welcomed.

In his introductory speech, Prof. Blaserna made a feeling reference to the death of King Edward, and several of the festivities prepared in honour of the meeting were modified in consequence of the Court mourning. A state dinner which the King had intended to give was changed into a private reception of the delegates, and in place of a garden-party arranged for by Queen Margherita, the Queen enterNO. 2 I I 7 , VOL. 83$]$ tained the delegates informally one afternoon at her palace. Soirées were given by the Syndics of the City of Rome in the Museo Capitolino, by Prince Teano and by Countess Lovatelli, but these were, as a matter of course, not attended by the British delegates. An interesting excursion by motor-car to Ostia, including a visit to the important excavations which are being carried out in that locality, concluded the meeting.

ARthur SCHUSTER.

\section{HALLEY'S OBSERVATIONS ON HALLEY'S}

\section{COMET, 1682 .}

$\mathrm{I}$ the record-room at the Royal Observatory, Greenwich, are preserved nineteen manuscripts of Edmund Halley. In one of these, Halley's original observations of the comet afterwards called by his name were recently discovered by Messrs. Davidson and Burkett. The book is of about octavo size; it appears to have been originally a college notebook. On the cover Halley has written "Edmund Halley his Booke and he douth often in it Looke." Part of the book contains neatly written notes (in English) on geometrical conics, with carefully drawn figures, chiefly written on aiternate pages. The observations (in Latin) and calculations have been jotted down subsequently wherever there is room, and in many cases have been written over the original contents of the book. By a strange coincidence (it can, I think, be no more than a coincidence) the observations, now identified as those of Halley's comet, are interspersed among notes on the parabola.

It will be recalled that Halley's researches which led to his discovery of the periodicity of this comet were not made until about twenty years after its appearance of 1682 ; in fact, the law of gravitation was not published until r686. It is, however, well known that Halley saw the comet, but I believe that details have hitherto been lacking.

The observations now identified are given below in full, with practically no changes, except that punctuation has been added. In the original, symbols are used for the days of the week and the signs of the zodiac. The observations, which must have been made with the naked eye, are almost entirely alignments with stars; they are, of course, too rough to have any scientific value now, but are of historic interest. Calculations to determine the R.A. of the comet from these observations are intermingled with them. Although the observations can hardly be correct to $15^{\prime}$, six-figure logarithms are used in the calculations! Halley, however, did not use his own observations in his determination of the orbit of the comet. The references to the "hand," "foot," "knee," "pastoral staff," \&c., of Boötes are of some interest as illustrating the early method of specifying stars, based on the Almagest.

The year is not given, but as the observations are certainly those of Halley's comet, and the days of the week agree, we may supply the date, I682.

Saturday, August 26, 7h. 29'. Culminante $277^{\circ}$ A.R., Cometa visus in linea recta cum Arcturo et capite Ophiuchi ; et ex altera parte cum Corde Caroli et secunda caudæ Ursæ Majoris; vel linea recta a cometa ad Im $^{\text {am }}$ caudæ Ursæ Majoris relinquebat in consequentia stellam dictam Cor Caroli $30^{\prime}$ A.R.

Tuesday, August 29, 7h. I $5^{\prime}$. Cometa in linea recta cum Arcturo et medium inter duas precedentes Coronæ, item in altera linea per Cor Caroli quæ relinquebat in conseq. stellam in radice caudæ Ursæ Majoris $30^{\prime}$; item in altera per genu præced. Bootis et medium inter contiguas dorsi ; item in altera per genu sequens et med. inter $3^{\mathrm{am}}$ et $4^{\mathrm{am}}$ Serpentis. Ascent. Recta Cometæ $19^{\circ}$ circiter.

Wednesday, August 30 . Culminante $280^{\circ}$ A.R., visus est Cometa in linea recta quæ transiens genu præced. 